\title{
NOTES
}

\section{TAXATION OF STOCK DIVIDENDS UNDER THE FEDERAL ESTATE TAX}

$\mathrm{U}_{\mathrm{NTxL}}$ 1954 the taxation of stock dividends under the federal income tax was uncertain. In 1920 the Supreme Court held in Eisner v. Macomber ${ }^{1}$ that stock dividends which did not alter the taxpayer's proportional interest in the assets of the corporation were not taxable income. In I936, Koshland v. Helvering ${ }^{2}$ held that a stock dividend which gave the shareholder an interest in the corporation different from that which he owned prior to the dividend was taxable income, regardless of whether his proportional interest was changed. Thus, for a number of years the "proportional interest" and "different in kind" tests determined the taxability of stock dividends. The unpredictable and sometimes inequitable results which they produced, ${ }^{3}$ however, prompted the enactment of section 305 of the 1954 Code,${ }^{4}$ which provides that stock dividends do not represent taxable income unless they are issued in lieu of dividends on preferred stock for the current or preceding year or unless the shareholder has an option to receive other property or cash in place of the stock dividend. 5

The "proportional interest" test, rejected by the 1954 Code, has been revived by the Treasury to tax stock dividends under the estate tax when such dividends have been declared on stock transferred in contemplation of death, ${ }^{8}$ on gift stock later placed in a joint tenancy with the donor, ${ }^{7}$

\footnotetext{
${ }^{1} 252$ U.S. I 89 (1920).

298 U.S. 441 (1936).

${ }^{3}$ See Dean, The Stock Dividend, 32 Taxes 586 (1954); Lowndes The Taxation of Stock Dividends and Stock Rights, 96 U. PA. L. REv. 147 (1947).

- Under the Int. Rev. Code of I939, ch. I, § I I5 (f) (x), 53 Stat. 47, a distribution of stock by a corporation to its shareholders was not treated as a dividend to the extent that it did not constitute income to the shareholder within the meaning of the sixteenth amendment. Under section I $_{5}(f)$ ( $I$ ) the tax of a given stock dividend was determined by applying the proportional interest theory of Eisner $v$. Macomber, supra note 1 , as modified by Koshland $v$. Helvering, supra note 2 , and subsequent court decisions.

${ }^{5}$ Section 305 is designed to postpone the tax on stock dividends until income is realized through their sale or other taxable disposition, without regard to whether or not a particular sharcholder's interest in the corporation, proportional or otherwise, has been varied. The tax loss resulting from a subsequent taxable disposition of the dividend shares at capital gains rates is mitigated by allocating the adjusted basis of the old stock between the old and new stock. INT. REv. CODE OF I954, $\$ 307(\mathrm{a})$.

${ }^{-}$Estate of Delia Crawford McGehee, 28 T.C. 412 (I957), rev'd, 260 F.2d 818 (5th Cir. 1958).

${ }^{7}$ Tuck v. United States, 172 F. Supp. 890 (N.D. Cal. I959).
} 
and on stock which is included in the decedent's estate on the alternate valuation date. ${ }^{8}$

In Estate of Delia Crawoford $M c$ Gehee, ${ }^{9}$ the decedent transferred by gift certain shares of stock in contemplation of death..$^{10}$ Subsequent to the transfer, but prior to her death, stock dividends representing the capitalization of current earnings were declared on the transferred shares and issued to the donees. ${ }^{11}$ The Tax Court ${ }^{12}$ included the value of the stock dividends in the decedent's gross estate ${ }^{13}$ on the theory that the gift of stock in contemplation of death transferred the decedent's entire proportional interest in the corporation and that stock dividends declared after the transfer were but a part of the proportional interest transferred. The Court of Appeals for the Fifth Circuit, ${ }^{14}$ however, traced the stock dividends to corporate profits earned after the transfer and reversed the Tax Court, holding that the dividends representing a capitalization of income earned subsequent to the date of transfer were not a proportionate part of the corporate assets at the time of the gift and therefore could not be regarded as part of the transfer. The court added by way of dictum, however, that, "Cases involving stock splits or

${ }^{8}$ Estate of John Schlosser, 32 T.C. No. 25 (April 30, 1959).

${ }^{\circ} 28$ T.C. 412 (1957), rev'd, 260 F.2d 818 (5th Cir. $195^{8}$ ).

${ }^{10}$ Int. Rev. Code of I939, $\S 8$ II (c), ch. 3, 53 Stat. I 21 .

This provision is substantially embodied in INT. REV. CODE OF 1954, § 2035 (a) which provides: "The value of the gross estate shall include the value of all property ... to the extent of any interest therein of which the decedent has at any time made a transfer (except in case of a bona fide sale for an adequate and full consideration in money or money's worth) ... in contemplation of death." Since 1954 the statute has conclusively presumed that all transfers made more than three years before the transferor's death were not made in contemplation of death. INT. REv. CODE OF 1954, $\S 2035$ (b).

${ }_{11}$ The transfers in question took place in 1947,1948 , and 1949 . The corporation had never declared a cash dividend, but from 194I through 1949 had followed a policy of capitalizing current earnings by a distribution of stock dividends.

${ }^{22}$ Estate of Delia Crawford McGehee, 28 T.C. 412, 415 (1957).

${ }^{13}$ The regulations provide that the transferred property interest includible in the gross estate is to be valued on the date of the decedent's death or on the alternate valuation date. Treas. Reg. $\$ 20.203$ I-I (b) (1958). See INT. REv. CoDE OF 1954, $\$ \S 2031$, 2032. Any increase in the value of the property resulting from improvements or additions by the transferee is not considered in determining the value of the gross estate, nor is income received subsequent to the transfer or property purchased with such income. Treas. Reg. $\$ 20.2035-1(e)$ (1958). For cases excluding cash dividends and other income from the value of the transferred property, see Commissioner v. McDermott's Estate, 222 F.2d 665 (7th Cir. 1955); Commissioner v. Gidwitz's Estate, r96 F.2d 813 (7th Cir. 1953); Burns v. Commissioner, I77 F.2d 739 (5th Cir. 1949).

${ }^{24}$ McGehee v. Commissioner, 260 F.2d 818 (5th Cir. 1958). 
stock dividends capitalizing corporate profits earned prior to the transfer might require different treatment."15

This dictum was applied in 1959 in Tuck $v$. United States, ${ }^{10}$ where stock dividends were declared on shares the decedent had transferred by gift to his wife. The original stock and the dividend shares were subsequently placed in joint tenancy between the decedent and his wife. Following his death the decedent's wife sought to exclude from his gross estate that part of the value of the jointly held stock attributable to the dividend shares she received while she was sole owner of the stock. She contended that, under the $M c$ Gehee case, the dividend shares originally belonged to her. ${ }^{17}$ The court held, however, that the dividend shares were taxable to the decendent's estate because it was not proved that they represented a capitalization of profits earned after the transfer. ${ }^{18}$

In Estate of John Schlosser, ${ }^{10}$ the executor elected to value the decedent's estate on the alternate valuation date. ${ }^{20}$ Subsequent to the decedent's death, but prior to the alternate valuation date, ${ }^{21}$ an eight-per cent stock dividend was declared and issued on shares of stock included in the gross estate. ${ }^{22}$ The issuing corporation declared the stock divi-

${ }^{16} I d$. at 820 .

${ }^{10}$ I72 F. Supp. 89̄o (N.D. Cal. 1959).

${ }^{17}$ Int. Rev. Code of $1939, \S 811(\mathrm{e})$, ch. 3,53 Stat. 122, substantially embodied in INT. REv. CODE OF 1954, $\$ 2040$, which requires that "the value of the gross estate shall include the value of all property ... to the extent of the interest therein held as joint tenants by the decedent and any other person . . . except such part thereof as may be shown to have originally belonged to such other person and never to have been reccived or acquired by the latter from the decedent for less than an adequate and full consideration in money or money's worth." See Treas. Reg. $\$ 20.2040$ (1958).

${ }^{18}$ Treas. Reg. 20.2040-I (c) (5) (1958). Cash dividends and other income produced by gift property and later placed in joint tenancy are excluded as property originally belonging to another person. See Harvey v. United States, 185 F.2d 463 (7th Cir. 1950). Accord, Ralph Owen Howard, 9 T.C. I192 (1947).

${ }_{10} 32$ T.C. No. 25 (April 30, 1959).

${ }^{20}$ Int. Rev. Code of $1939, \$ 8 \mathrm{II}(\mathrm{j})$, ch. 3,53 Stat. 122, now INT. REv. Code of 1954, $\$ 2032$. The statute permits the executor to elect to value all the property included in the gross estate as of the date one year after the decedent's death, with the exception that property distributed, sold, exchanged, or otherwise disposed of before the end of the one-year period following death shall be valued as of the date of its distribution, sale, exchange, or other disposition. See Treas. Reg. $\$ 20.2032$ (1958). Prior to the Internal Revenue Code of 1954, the practice was termed the optional method.

${ }^{21}$ The statute is interpreted as permitting the alternate valuation on the anniversary of the decedent's death. See Treas. Reg. $\$ 20.2032-1(e)$ (1958). In the instant case, where the decedent died on January 25,1953 , the alternate valuation date was January 25,1954 .

${ }_{22}$ The decedent held 10,394 shares of Sun Oil Co. common stock at his death. The stock dividend added 83 I shares to his holdings. 
dends from current earnings, ${ }^{23}$ and, when the shares were issued, transferred from earned surplus to its capital account an amount equal to the assigned value of the dividend shares. The Tax Court, finding support in an administrative interpretation ${ }^{24}$ of Section 2032 of the Code, held that the shares received as stock dividends were taxable property within the meaning of that section and the applicable regulations, ${ }^{25}$ and upheld the Commissioner's determination that they be included in the gross estate at their fair market value on the alternate valuation date.

The usual standard of valuation under the estate tax is the fair market value of the property on the date of the decedent's death. ${ }^{26}$ During the depression years, this standard produced extreme hardship where a sudden decline in the market value of the taxable property following the decedent's death reduced the value of his estate so that a sale of all the property was sometimes necessary to pay the estate tax. To provide some protection against the complete confiscation of estates under such circumstances, ${ }^{27}$ the alternate valuation method, which permits the executor to value the estate one year after the date of death, was authorized by the Revenue Act of $1935 .^{28}$

The Treasury Regulations ${ }^{29}$ interpreting this provision enumerated several types of property and established standards for determining their inclusion in the gross estate when the alternate valuation date was

\footnotetext{
${ }^{23}$ On October 20, 1953, the directors announced that the dividend was to be issued on December $15^{\text {th }}$ to the shareholders of record on November 13 th. Each dividend share was assigned a value of $\$ 65$. The earnings for the year ending December 31, I953, exceeded the aggregate value of the stock and cash dividends during the year. Estate of John Schlosser, 32 T.C. No. 25 (April 30, 1959).

${ }^{24}$ Rev. Rul. 58-576, 1958-2 CUM. Bull. 625, 626 provides: "The declaration of the stock dividend after the decedent's death directly affects the value of the shares of stock at the subsequent valuation date so that the decedent's shares of stock in the corporation at the subsequent valuation date no longer reasonably represent the same property interest in the corporation possessed by the decedent at the time of his death. Such a dividend is 'included property' as that term is defined in section 20.2032-1 of the regulations."

${ }_{25}$ Treas. Reg. $\$ 20.2032-I(d)$ (I958). Although the court did not expressly accept the "proportional interest" test, it cited with approval Prof. Paul, who indicates that, under Eisner v. Macomber, stock dividends declared during the alternate valuation period should be included in the subsequent valuation. Estate of John Schlosser, 32 T.C. No. 25 (April 30, 1959). See 2 PaUl, Federal Estate and Gift Taxation 1342 (1942).

26 Treas. Reg. $\$ 20.2031-1$ (b) (1958).

${ }^{27}$ See S. REP. No. 1240, 74th Cong., 1st Sess. 9 (1935).

${ }^{28}$ Revenue Act of 1926, $\$_{302}(\mathrm{j})$, added by ch. 829, 49 Stat. 1022 (1935).

${ }^{20}$ Treas. Reg. 80, § II (1937).
} 
elected. ${ }^{30}$ The regulations applicable to corporate stock required that all dividends received or accrued during the year following death be included in the gross estate on the alternate valuation date..$^{31}$

In Maass v. Higgins, ${ }^{32}$ however, the Supreme Court reached a different conclusion as to the property includible in the gross estate on the alternate valuation date. Section $302(j)$ of the Revenue Act of 1926 provided that the value of the gross estate should be determined one year after the decedent's death by valuing at that time all the property included in the gross estate on the date of the decendent's death..$^{33}$ Under the usual method of valuation, only those dividends accrued on the date of the decedent's death are included in the gross estate. Since neither the langauge of the statute nor the committee reports ${ }^{34}$ indicated a congressional intention that different methods or different property be considered when the alternate valuation date was elected, the Court properly concluded that only those dividends accrued on the date of death would be included in the estate on the alternate date, and those dividends accrued after the decedent's death would be excluded. ${ }^{35}$

Following Maass v. Higgins, ${ }^{36}$ the Treasury amended the regulations $^{37}$ to provide for two classes of property interests. All property interests existing at the decedent's death which formed a part of his gross estate were "included property" and were taxed when the estate

\footnotetext{
${ }^{30}$ In general, the regulations asserted that property was composed of two distinct elements-primcipal and right to income from the principal. More specifically, they considered that all property interests included in the gross estate such as bonds, notes, and those interests calling for payment of rents or royalties, embodied two valuation elements: The value of the principal and the value of the right to receive interest or rent for the use of the principal. Proceeding on this theory the regulations required that all amounts received or accrued during the one-year period after death with respect to property interests included in the gross estate at death, be included in the gross estate on the alternate date. Treas. Reg. 80, § II (1937).

${ }^{31}$ Ibid.

${ }_{32}^{32}$ U.S. 443 (1941).

${ }^{33}$ Revenue Act of $1926, \S_{302}(\mathrm{j})$, added by ch. 829,49 Stat. 1022 (1935).

34 CoNf. REp. No. 1885, 74th Cong., Ist Sess. io (1939), reprinted 1939-I, part 2 CUM. Bull. 663-64. But see, 2 PAUL, op. cit. supra note 25, at 1335 n.7.

${ }^{35}$ Mass v. Higgins, $3 \times 2$ U.S. 443, 448-49 (1941). The Court apparently sought to avoid double taxation. Id. at 449. See 2 PAUL, op. cit. supra note 25, at 1336 . A clearer statement of the inclusion principle is found in Clark v. United States, 33 F. Supp. 216,221 (D. Md. 1940), where the court held that "... property which is to be valued clearly must be that which was in existence at the date of the death of the decedent and was then properly included in the gross estate."

${ }^{30} 312$ U.S. 443 (1941).

${ }^{37}$ Treas. Reg. 80, $\S_{\text {II }}$ (1937), as amended, T.D. 5047, 1941-I CUM. BULL. 425 (now Treas. Reg. § 20.2032-I(d) (1958)).
} 
was valued on the alternate valuation date, but all property interests earned or accrued after the decedent's death were termed "excluded property" and were not taxed on the alternate valuation date. The amended regulations expressly covered dividends declared after the decedent's death. They provided that, "Ordinary dividends out of earnings and profits, whether in cash or shares of the corporation or in other property ..." were not to be included in the estate under the alternate method. If, however, the dividends altered the value of the included shares so that, on the alternate valuation date, they did not reasonably represent the same included property as existed at the decedent's death, the dividends were to be included in the gross state on the alternate valuation date, except to the extent that they represented profits earned after the decedent's death. ${ }^{38}$ The express language of the amended regulations indicates that the McGehee "tracing" principle is applicable and that stock dividends capitalizing corporate profits earned after the decedent's death shall be excluded property when the alternate valuation date is employed, ${ }^{39}$ Revenue Ruling $58-576^{40}$ not withstanding.

Two theories, then, have emerged with regard to the taxation of stock dividends under the estate tax. The McGehee $e^{41}$ and $T u c k^{42}$ cases apply the "tracing" principle, and determine the taxability of stock dividends by tracing them to the earnings from which they were declared. If the shares can be attributed to a capitalization of current earnings accruing after the underlying shares were transferred, or after the decedent's death if the alternate valuation method is used, they will not be taxed under the estate tax. ${ }^{43}$ The utility of this method is impaired, however, by the difficult questions of fact and allocation which it raises. ${ }^{44}$

The Tax Court and the Treasury, on the other hand, contend that stock dividends which are not income should be taxed to the estate re-

${ }^{38}$ Ibid.

${ }^{30}$ Treas. Reg. $\$ 20.2032-\mathrm{I}$ (d) (4) (1958), currently in effect, employ substantially the same language as the amended regulations under the 1939 Code, and indicate that a stock dividend would have to be declared entirely from accumulated earnings and profits before its value could be included in the gross estate on the alternate valuation date.

${ }^{40}$ Rev. Rul. 58-576, 1958-2 Cum. Bull. 625 .

${ }^{41} 260$ F.2d 818 (5th Cir. 1958), reversing 28 T.C. 412 (1957).

42 I72 F. Supp. 890 (N.D. Cal. 1959).

43 The method is analagous to the "Pennsylvania rale," which was formerly approved by the Restatement of Trusts for allocating receipts from shares of stock between income and principal beneficiaries. RESTATEMENT, TRUSTS $\$ 236(\mathrm{a})$, comments $c$ and $h$ (1935). The section has been amended to provide that all stock dividends constitute principal. RESTATEMENT (Second), TRUSTS $\$ 236$ (b) (1959).

"Restatement, Trusts $\$ 236(\mathrm{a})$, comment $c$ (1935). 
gardless of their source. In establishing whether a given stock dividend is income, two alternatives are available: the common-law principle of Eisner v. Macomber, ${ }^{45}$ holding that stock dividends which fail to alter the shareholder's proportional interest in the corporation are not income, and the more recent expression of section $305{ }^{46}$ which provides that stock dividends are not income except when declared in discharge of dividends on preferred shares for the current or preceding taxable year, or when the shareholder is given the option of receiving cash or other property in lieu of the dividend shares. To date, the Tax Court has employed only the common-law "proportional interest" test, but its use encourages litigation, and it is subject to the same myriad interpretations as led to its replacement under the income tax. ${ }^{47}$

Perhaps it is impossible, on purely equitable grounds, to devise a method of taxing stock dividends under the estate tax which would be fair to all interests involved. In view of the difficulties inherent in the use of the common-law "tracing" principle and "proportional-interest" test, it would seem that the most practical solution to the problem could be reached by applying to the particular stock dividend involved the pragmatic test provided in section 305 of the Code and by including in the decedent's gross estate on the applicable valuation date the value of those dividend shares failing to qualify as income.

\footnotetext{
${ }^{45} 252$ U.S. 189 (1920).

"INT. REv. CODE OF 1954 .

${ }^{67}$ See note 3 supra. See also, S. Rep. No. 1622,83 d Cong., 2d Sess. 44 (1954).
} 